MaPan : Jurnal Matematika dan Pembelajaran

p-ISSN: 2354-6883 ; e-ISSN: 2581-172X

Volume 8, No 2, Dec 2020 (179-204)

DOI: https://doi.org/10.24252/mapan.2020v8n2a2

\title{
WRITTEN MATHEMATICAL COMMUNICATION SKILLS ON OPEN- ENDED PROBLEMS: IS IT DIFFERENT BASED ON THE LEVEL OF MATHEMATICS ABILITY?
}

\author{
Septi Dariyatul Aini'), Moh. Zayyadi'2), Kuratul Aini Saleh' \\ 1,2,3Pendidikan Matematika, Universitas Madura \\ 1,2,3 Jl. Panglegur Nomor Km 3,5, Pamekasan, Madura, Jawa Timur \\ E-mail: septi_math@unira.ac.id11, zayyadi_math@unira.ac.id2), \\ kuratulainisaleh@gmail.com ${ }^{3)}$
}

Received September 07, 2020; Revised October 21, 2020; Accepted December 02, 2020

\begin{abstract}
:
This study aims to describe students' written mathematical communication skills in open-ended problems based on their mathematical abilities. This research was conducted at grade VII-A of SMPN 1 Pamekasan. This research uses descriptive qualitative research. The instruments used were the Mathematical Ability Test (MAT), Written Mathematical Communication Skills Test (WMCST) on open-ended problems, and Interview Guidelines. The results showed that subjects with high and moderate mathematical ability were able to meet three indicators of written mathematical communication skills, namely being able to express mathematical ideas through writing, demonstrate and convey visually; able to understand, interpret and evaluate mathematical ideas in writing, as well as in other visual forms; and able to use mathematical notations in the structure to write down ideas and relationships with situation models in writing. Meanwhile, subjects with low mathematics ability can fulfill 2 out of 3 indicators of written mathematical communication skills, namely being able to express mathematical ideas through writing, demonstrate and convey visually; unable to understand, interpret and evaluate mathematical ideas in writing or other visual forms; and able to use mathematical notations in the structure to write ideas and relationships with situation models.
\end{abstract}

Keywords: Written Mathematical Communication, Open Ended

\section{KEMAMPUAN KOMUNIKASI MATEMATIS TERTULIS PADA MASALAH OPEN ENDED: APAKAH BERBEDA BERDASARKAN TINGKAT KEMAMPUAN MATEMATIKA?}

\begin{abstract}
Abstrak:
Penelitian ini bertujuan untuk mendeskripsikan kemampuan komunikasi matematis tertulis siswa pada masalah open ended berdasarkan kemampuan matematika. Penelitian ini dilaksanakan di kelas VII-A SMPN 1 Pamekasan. Penelitian ini menggunakan penelitian deskriptif kualitatif. Instrumen yang digunakan adalah tes kemampuan matematika, tes kemampuan komunikasi matematis tertulis pada masalah open ended, dan pedoman wawancara. Hasil penelitian menunjukkan bahwa subjek berkemampuan matematika tinggi dan sedang mampu memenuhi 3 indikator
\end{abstract}

Copyright @ 2020, MaPan : Jurnal Matematika dan Pembelajaran 
kemampuan komunikasi matematis tertulis yaitu mampu mengekspresikan ide-ide matematis melalui tulisan, mendemonstrasikan serta menyampaikan secara visual; mampu memahami, menginterpretasikan dan mengevaluasi ide-ide matematis secara tulisan, maupun dalam bentuk visual lainya; dan mampu dalam menggunakan notasinotasi matematika dalam strukturnya untuk menulis ide- ide dan hubungan dengan model situasi secara tertulis, sedangkan subjek berkemampuan matematika rendah dapat memenuhi 2 dari 3 indikator kemampuan komunikasi matematis tertulis yaitu mampu mengekpresikan ide-ide matematis melalui tulisan, mendemonstrasikan serta menyampaikan secara visual; tidak mampu memahami, menginterpretasikan dan mengevaluasi ide- ide matematis secara tulisan, maupun dalam bentuk visual lainya; dan mampu dalam menggunakan notasi-notasi matematika dalam strukturnya untuk menulis ide ide dan hubungan dengan model situasi secara tertulis.

Kata Kunci: Komunikasi Matematis Tertulis, Open Ended

How to Cite: Aini, S. D., Zayyadi, M., \& Saleh, K. A. (2020). Written Mathematical Communication Skills on Open-Ended Problems: Is It Different Based on The Level of Mathematics Ability? MaPan : Jurnal Matematika dan Pembelajaran, 8(2), 179-204. https://doi.org/10.24252/mapan.2020v8n2a2.

\section{INTRODUCTION}

$\mathrm{I}$

n Permendiknas Number 22 of 2006 concerning Standard Content of Mathematics Subjects, one of the objectives to be achieved in mathematics learning is the ability to communicate ideas about mathematical objects being studied by students. In this case, communication skills are very important to raise a problem and solve it. Students need to be trained to have the ability to communicate in mathematics learning. Communication skills become one of the conditions that play an important role as it helps in the process of preparing thought and connecting ideas with other ideas that can fill up the things lacking in the whole network of students' ideas (Syafitri, Saragih, \& Astuti, 2018: 587).

Communication is the process of conveying meaning in the form of ideas or information from one person to another through certain media (Hardjana, 2003: 11). Agree with Roger in Majid (2016: 282), which defines communication as a process in which there is an idea that is sent from the source to the recipient to change its behavior so that communication requires more than one person and one of them as a source (sender) and the other as a receiver of information and ideas in the hope of giving new knowledge to the receiver. In mathematics, receiving and conveying information is not easy. This is due to the mathematics with lots of terms and symbols. Therefore, communication in mathematics needs to be owned by every student. 
According to Guerreiro and Serrazina (2009), mathematical communication is a tool in the transmission of mathematical knowledge. Communication makes mathematical thinking observable and therefore communication facilitates the development of thinking. Agree with Agustyaningrum (2011), mathematical communication is a way for students to express mathematical ideas either verbally, in writing, pictures, diagrams, using objects, presenting in algebraic form, or using mathematical symbols. The Ministry of National Education in Agustyaningrum (2011: 24) also states that mathematical communication is the ability of students to express and interpret mathematical ideas orally, in writing, or to demonstrate what is in mathematical problems. So, it can be concluded that mathematical communication is a student's way of conveying mathematical ideas either orally, in writing, pictures, diagrams, using objects, presenting in algebraic form, or using mathematical symbols.

Communication in learning mathematics is called mathematical communication. Greenes and Schulman explained that mathematical communication is the capital in completing, exploring, and investigating mathematics which is used as a forum for social activities with friends, sharing thoughts and discoveries, brainstorming, evaluating, and sharpening ideas to convince others (Herdiana, Rohaeti, \& Sumarmo, 2018). The purpose of mathematical communication is to encourage students to be able to encourage, share support about mathematics (Kaya \& Aidin, 2014).

Mathematical communication skills are the basic skills that students must have in learning mathematics. The communication process can help students develop an understanding of concepts in mathematics and easy to understand (Herdiana, Rohaeti, \& Sumarmo, 2017). Oral and written communication can bring students a deep understanding of mathematics. Graphs, charts, diagrams, symbols, and equations are ways of communication that are often used in mathematics. Tables, diagrams, and graphs lead students to make conclusions, predictions, and new questions. Through tracing patterns and equations, students learn to communicate an understanding of the sequence and subsequent repetition symbolized using a picture or symbol.

Aspects of mathematical communication skills according to NCTM in Susanto (2013: 215) consist of three, namely: a) the ability to express mathematical ideas through oral, written, and demonstrate and describe them visually; b) the ability to understand, interpret, and evaluate mathematical ideas both verbally and in other visual forms; and c) the ability to use terms, 
mathematical notations, and structural structures to present ideas, describe relationships and model situations. In this case, written mathematical communication skills need to be possessed by every student.

Ansari (2003) says that written mathematical communication is the ability and skills of students to use vocabulary, notation, and mathematical structures to express relationships and ideas in solving mathematical problems logically and completely. Thus, Qohar (2011) argues that written mathematical communication is the ability to express and illustrate mathematical ideas in the form of mathematical models. So, written mathematical communication skills are the ability to describe thoughts from the mathematical language. The written mathematical communication ability indicators used in this research were adapted from Wijaya, Surjadi, and Riyadi (2016), namely: (1) ability to express mathematical ideas through writing, demonstrate and convey visually; (2) ability to understand, interpret and evaluate mathematical ideas in writing, as well as in other visual forms; (3) ability to use mathematical notation in its structure to convey written ideas and relationships with situation models.

From the above statement, evaluating written mathematical communication skills is not easy so that students need to be guided by using open-ended problems as a tool to determine students' communication skills. Open-ended is a learning approach by presenting problems that have more than one correct solution or more than one correct answer so that students actively develop different methods, or approaches to solve the problems given (Suherman, Turmudi, Herman, \& Suhendra, 2001: 113). Agree with Inprasitha (2006) states that an open-ended approach begins by involving students in open problems and is formulated to have the correct answer "incomplete" or "open". By using open-ended mathematical problems, it will stimulate written mathematical ability, because in open-ended problems students are given openended problems that can give students flexibility in thinking in solving a problem. Advantages of using open-ended problems are many: students participate more actively in lessons, they express their ideas more frequently, each student can answer the problem in his/her own and unique way, students are developing mathematical and creative thinking. Moreover, those problems give students more opportunities to make comprehensive use of their mathematical knowledge, skills, and abilities (Burghes \& Robinson, 2009).

From the above background, the researcher wants to research "Written Mathematical Communication Skills on Open Ended Problems: Is It Different Based on Mathematics Ability?" 


\section{METHODS}

This type of research is qualitative with a descriptive approach. As explained by Fraenkel, Wallen, and Hyun (2008: 422), namely; “Research studies that investigate the quality of relationships, activities, situations, or materials are frequently referred to as qualitative research". This research was conducted in the even semester in grade VII of SMPN 1 Pamekasan. The subjects in this study were three students from grade VII of SMPN 1 Pamekasan. The procedures for selecting research subjects were: (1) Determining the research class from grade VII SMPN 1 Pamekasan. In this study, the research class is grade VII-A SMPN 1 Pamekasan which consists of 32 students. The reason the researcher chose this grade VIIA student was based on the information from the mathematics teacher where this class was the most complex and representative of the regular class in choosing subjects with high, medium, and low mathematics abilities compared to the other regular classes. Making it easier for researchers to choose research subjects. (2) Select three research subjects. The researcher chose three subjects from the selected class with low, medium, and high mathematics ability. Therefore, the researcher conducted a mathematics ability test first to find out which students have low, medium, and high ability. Then from each of the results of the mathematics ability test, 3 research subjects were selected with the category of high mathematics ability, namely $80 \leq$ mathematical ability $\leq 100$, medium mathematics ability, namely $65 \leq$ mathematical ability $\leq 80$, and low mathematics ability if mathematical ability $<65$. (3) Can communicate well. Determining the subject also takes into account the teacher's considerations related to the subject's communication skills to express their opinion or way of thinking orally or in writing. The importance of researchers considering the communication skills of the subject, the goal is that the disclosure of mathematical communication skills with open-ended problems can be done well. (4) Willing to be the subject of research.

For the function of the researcher as the main instrument to run well, it is necessary to have assistive instruments in the form of mathematics ability test, test of mathematical communication skills on open-ended problems, and interview guideline. The mathematics ability test is used to take three research subjects from the high, medium, and low categories. The test is in the form of essay questions and adapted from the National Examination (UN) questions for the last three years. The written mathematical communication skill test (WMCST) on open-ended problems was used to obtain data about the students' written mathematical communication skills in open-ended problems in grade 
VII SMPN 1 Pamekasan. The form of this test consists of questions that refer to Wijaya's opinion about aspects of mathematical communication skills that will be measured in this study include: (1) the ability to express mathematical ideas through writing, demonstrate and convey them visually; (2) the ability to understand, interpret and evaluate mathematical ideas in writing, as well as in other visual forms; (3) the ability to use mathematical notation in its structure to convey written ideas and relationships with the situation model. The interview guideline was made based on the explanation of each indicator of mathematical communication skills. Interviews were conducted to clarify students' answers to open-ended questions that had been done. Besides, interviews were conducted to reveal further information provided by students. Through interviews, students can be more clearly express their answers so that it will be easier for researchers to analyze the answers they give. The interview method used is a semi-structured method because the questions given during the interview depend on the situation, skills, and answers given. The interview guideline used in this study is as follows.

Table 1. Interview Guideline for Written Mathematical Communication Skills

\section{Written Mathematical \\ Communication Ability Indicators \\ Research Questions}
(1) Ability to express a. After reading the questions, do you mathematical ideas understand what the questions mean?
through writing, b. What is known from the question? demonstrate and convey c. After you understand what the problem is, visually what ideas do you have in mind?
d. in what ways did you come up with the idea?

(2) Ability to understand, a. Try to explain why you used this idea? interpret and evaluate b. Next, try expressing each step of your mathematical ideas in writing, as well as in other visual forms answer

c. After you have expressed all your answers, are you sure of your answers?

d. After solving the questions, are you used to proofread them again?

e. What do you usually do to proofread your answers?

(3) Ability to mathematical notation in its structure to convey use a. Try to state what mathematical symbols or notations did you use in solving this problem? 
written ideas and b. Why do you use these mathematical relationships with symbols or notations?

situation models. $\quad$ c. What is the relationship between the symbols or mathematical notation?

Before being used, the mathematical ability test (MAT) instrument, the written mathematical communication skills test (WMCST) instrument on the open-ended problem test, and the interview guideline were validated by two validators with the following conditions: (1) feasible to use if at least two validators said they were feasible to use; (2) feasible to be used with improvement if at least two validators say it is suitable to be used with improvements or one validator says it is suitable for use and one validator says it is suitable to be used with improvements; (3) It is not suitable for use if at least two validators say it is not suitable for use.

In this study, the data analysis techniques used were data reduction, data display, and conclusion drawing. Meanwhile, to check the validity of the data, the researcher used time triangulation technique by comparing and checking the results of the test questions carried out at different times using the same questions or having the same level of difficulty. By giving different tests with an equal difficulty level, consistency, and accuracy of data obtained regarding mathematical communication skills in open-ended problems become valid and reliable. The details of time triangulation technique in this study are explained as follows: (1) Tests and interviews were carried out on tests of written mathematical communication skills on open-ended problems, which are hereinafter referred to as tests and interviews 1. At different times, tests and interviews were carried out on tests. written mathematical communication skills on open-ended problems (equivalent to test questions 1), hereinafter referred to as tests and interviews 2. (2) The results of the test and interview 1 are compared with the results of the second test and interview if the same trend is obtained, data collection on the research subject is complete and conclusions can be drawn. If the same trend is not obtained, tests and interviews are conducted on tests of written mathematical communication skills on open-ended problems (equivalent to test questions 1 and 2), hereinafter referred to as tests and interviews 3. (3) If the results of tests and interviews 3 tend to be the same as the results of tests and interviews 1 , then the data on written mathematical communication skills tests on open-ended problems is obtained from the results of tests and interviews 1 and 3. If the results of tests and interviews 3 tend to be the same as the results of tests and interviews 2, then data on written 
mathematical communication skills tests on open-ended problems were obtained from the results of tests and interviews 2 and 3. (4) If the comparison of all the data still has a different tendency, a written mathematical communication skill test and interview will be carried out on an open-ended problem repeatedly until valid data is obtained. Data or information is said to be valid if there is consistency, the similarity of views, opinions, or thoughts on the results of tests and interviews conducted by researchers.

\section{RESULT AND DISCUSSION}

Based on the data recapitulation of student scores in terms of mathematical ability, the research subjects taken were (1) students who have high, medium, and low mathematics scores and mathematics skills tests; (2) can communicate well; (3) willing to be the subject of research. The names of research subjects in this study are as follows: (1) RLH as a subject of high mathematics ability (SHMA), (2) APA as a subject of medium mathematics ability (SMMA), and (3) TPL as a subject of low mathematics ability (SLMA).

Then to find out students 'mathematical communication skills in Openended problems, the researcher conducted two tests using WMCST 1 and WMCST 2. In the following, WMCST 1 and WMCST 2 were presented in this study to determine students' mathematical communication skills in open-ended problems.

\section{Written Mathematical Communication Skills Test 1 (WMCST 1)}

Mr. Fikri wants to hold his son's wedding. He plans to make a luxurious stage. Mr. Fikri plans to make a stage in the shape of an upright $\mathrm{T}$. With an upright size of $5 \mathrm{~m} \times 5 \mathrm{~m}$, while the horizontal size is $15 \mathrm{~m} \times 5 \mathrm{~m}$. Around the stage, decorations are installed at a cost of Rp 5.000,00 each meter. The entire surface of the stage is covered with carpets with a rental fee of IDR Rp 8.000,00 $\mathrm{m}^{2}$ each. Determine:

a. The area of the stage

b. The cost of installing all the decorations;

c. All carpet rental costs;

Figure 1. Written Mathematical Communication Skills Test 1 (WMCST 1) 


\section{Written Mathematical Communication Skills Test 2 (WMCST 2)}

SMAN 2 Pamekasan helds a farewell ceremony. The school plans to make a luxurious stage. The stage is L-shaped. With an upright size of $6 \mathrm{~m} \times 6 \mathrm{~m}$, while the horizontal size is $18 \mathrm{~m} \times 6 \mathrm{~m}$. Around the stage, decorations are installed at a cost of $\operatorname{Rp} 15.000,00$ each meter. The entire surface of the stage is covered with carpet with a rental fee of $\mathrm{Rp}$ 18.000,00 $\mathrm{m}^{2}$ each. Determine:

a. The area of the stage

b. The cost of installing all the decorations;

c. All carpet rental costs;

Figure 2. Written Mathematical Communication Skills Test 2 (WMCST 2)

The following will explain the results of the analysis of students' mathematical communication skills in open-ended problems.

\section{High Mathematics Ability Subject}

The following is an excerpt from an interview with SHMA on Openended problems at WMCST 1.

Researchers: Are you ready to be interviewed?

SHMA : Yes

Researchers: After reading the questions, do you know the meaning of the questions?

SHMA : Yes

Researchers: Furthermore, what is known from the question?

SHMA : The size of the stage and the price per meter of decoration and the cost of renting the carpet

Researchers: Is anything else known?

SHMA : Nothing

Researchers: After you know what you mean and you know what idea comes to your mind?

SHMA : Drawing a perpendicular stage

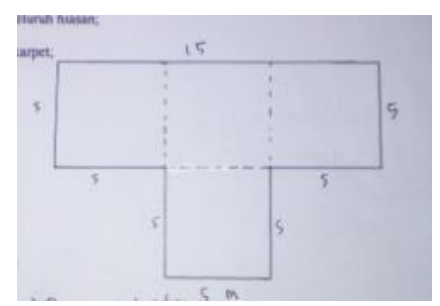

Researchers: In what ways did you come up with these ideas? 
SHMA : By drawing a perpendicular stage

Researchers: Try to explain why you used this idea?

SHMA : To find out the meaning of the questions so that they can be better understood and able to answer

Researchers: Next try expressing each step of the answer you?

SHMA : Finding the area of the stage first, looking for the circumference by multiplying the cost per meter, the rental fee per meter multiplied by the area of the stage

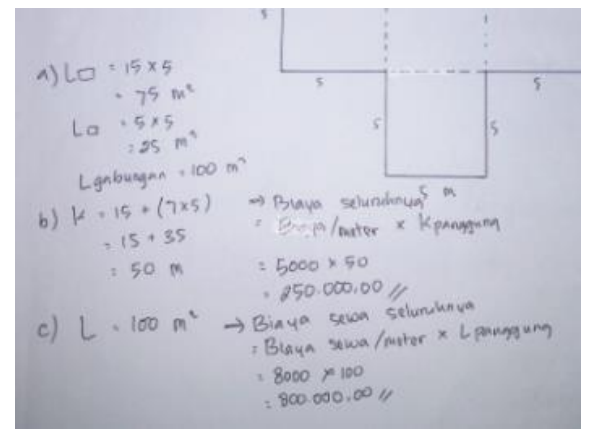

Researchers: How many buildings were there on that stage?

SHMA : There are 2 buildings. Build rectangles and squares

Researchers: How do you find the stage area?

SHMA : Find the area of a rectangle and find the area of a square. Then add up the result $100 \mathrm{~m}^{2}$

Researchers: Is there any other way to find the stage area?

SHMA : Yes. In this way, the shape is made into a square all and the result is the same $100 \mathrm{~m}^{2}$

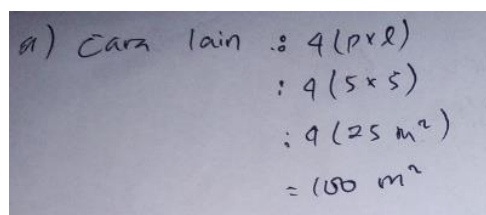

Researchers: Is there any other way to find installation fees for the whole decoration?

SHMA : You add up all the sides

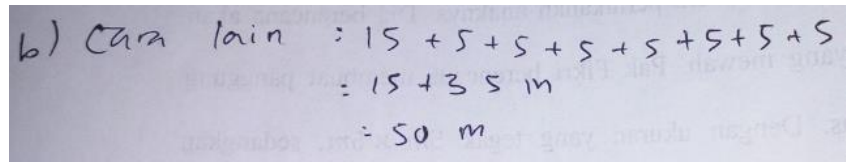

Researchers: To find the entire carpet for rent, is there another way?

SHMA : No, because the method is the same for everyone. Multiplying rental costs per meter by the stage area.

Researchers: After you have expressed all your answers, are you sure about your answer?

SHMA : Yes, sure

Researchers: After solving the questions, are you used to proofread? 
SHMA : Yes

Researchers: What do you usually do to proofread again your answer?

SHMA : Recalculating from scratch.

Researchers: Please state what mathematical symbols or notations do you use in solving problems?

SHMA : Multiplication and addition.

Researchers: Why do you use symbols or notations in mathematics?

SHMA : For easier finding the answer.

Researchers: What is the relation of mathematical symbols or notations?

SHMA : To find out the results.

The following is an excerpt from an interview with SHMA on Openended problems at WMCST 2.

Researchers: Are you ready to be interviewed?

SHMA : Yes

Researchers: After reading the questions, do you know the meaning of the questions?

SHMA : Yes

Researchers: Furthermore, what is known from the question?

SHMA : L-shaped stage with an upright size of $6 \times 6 \mathrm{~m}$ and $18 \times 6 \mathrm{~m}$ horizontal, decoration costs each meter and rental fee each meter

Researchers: Is anything else known?

SHMA : Nothing

Researchers: After you know what you mean and you know what the idea comes to your mind?

SHMA : Drawing

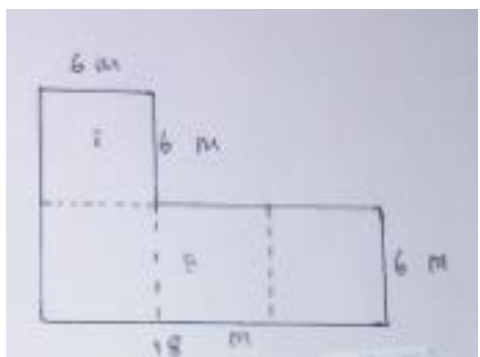

Researchers: In what ways did you come up with these ideas?

SHMA : By drawing a perpendicular stage

Researchers: Try to explain why you used this idea?

SHMA : To find out the meaning of the question so that it is better understood

Researchers: Next try expressing each step of the answer you? 
SHMA : Finding the area of the stage first, looking for the circumference by multiplying the cost per meter, the rental fee per meter multiplied by the area of the stage

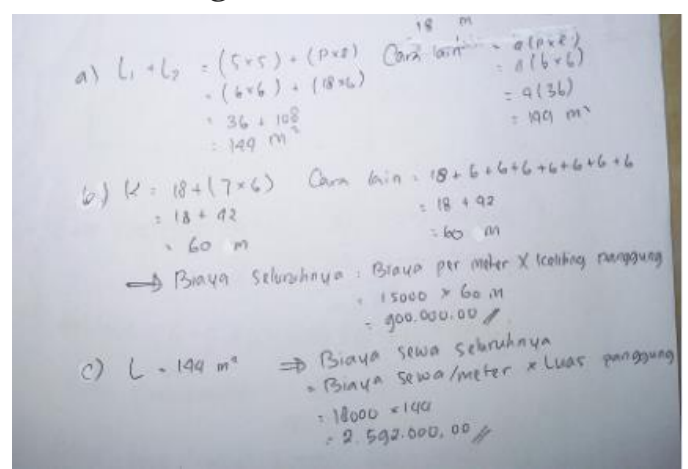

Researchers: How many buildings were there on that stage?

SHMA : There are 2 buildings. Build rectangles and squares

Researchers: How do you find the stage area?

SHMA : Find the area of a rectangle and find the area of a square. Then the result is $144 \mathrm{~m}^{2}$

Researchers: Is there any other way to find the stage area?

SHMA : Yes. By making all the squares. There are 4 squares build to 4 ( $p \times$ l) and the result is the same $144 \mathrm{~m}^{2}$

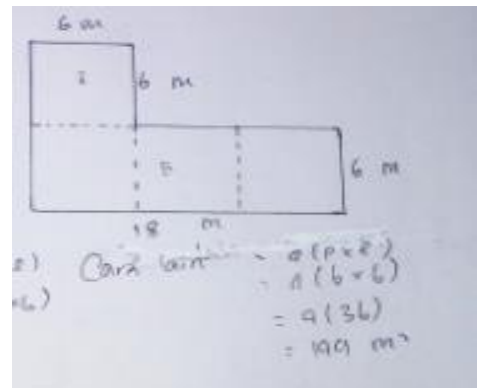

Researchers: Is there any other way to find installation costs for the whole decoration?

SHMA : You add up all the sides

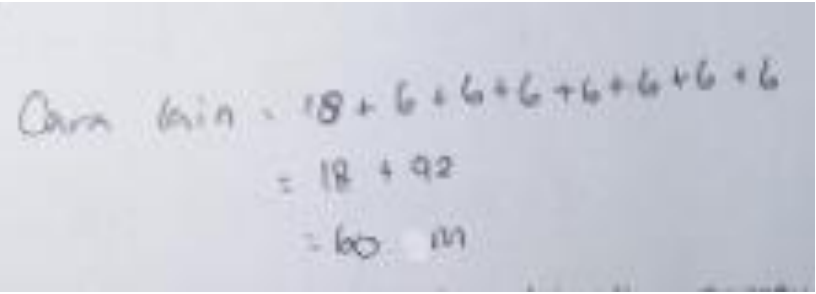

Researchers: To find the entire carpet for rent is there any other way?

SHMA : No, because the methods are all the same. Multiplying rental costs per meter by the stage area.

Researchers: After you have expressed all your answers, are you sure about your answer?

SHMA : Sure

190 | Volume 8, No 2, December 2020 
Researchers: After solving the questions, are you used to proofread?

SHMA : Yes, I'm used to it

Researchers: What do you usually do in proofreading your answer?

SHMA : Recalculate from scratch reading from scratch.

Researchers: Please state what mathematical symbols or notations do you use in solving problems?

SHMA : Multiplication and addition.

Researchers: Why do you use symbols or notations in mathematics?

SHMA : To make it easier to find the answer.

Researchers: What is the relationship between symbols or mathematical notation?

SHMA : To find out the results being asked.

Based on interview quotes and answers to subjects with high mathematics ability, it is revealed that subject can meet all indicators of written mathematical communication skills, namely subject is able to express mathematical ideas through writing, demonstrate and convey visually; the subject is able to understand, interpret and evaluate mathematical ideas in writing, as well as in other visual forms; and the subject is able to use mathematical notation in its structure to write ideas and relationships with situation models. Subject is able to express mathematical ideas through writing by expressing the size of the stage as well as the cost of perimeter decoration and carpet rental costs and demonstrating and conveying visually by drawing a perpendicular stage. Subject is able to understand by finding the area of the stage first, looking for the perimeter by multiplying the cost per meter and per meter rental fee times the stage area, and interpreting by expressing the shape of the stage consisting of 2 rectangular and square shapes, and evaluating mathematical ideas in writing or other visual forms using different methods or solutions. Subject can use mathematical notations of multiplication and addition to more easily find answers in their structure to write ideas and relationships with situation models in writing, namely to find answers.

In general, it can be concluded that the subject with high mathematics ability can meet the three indicators of written mathematical communication skills. This is in line with the results of research by Nastahwid, Irawan, and Susanto (2016: 620) that the students' answers show that students have met the communication standards of NCTM (2020). Like the answers shown by S1 and $\mathrm{S} 2$, it can be seen in problem 1 that students have used mathematical language to express mathematical ideas correctly, namely making assumptions from each of the known data in the problem. Likewise in problem 2, students have used 
the language of mathematics to express mathematical ideas correctly, namely making assumptions from each of the data that has been known in the problem. The first step that S1 and S2 do is express their mathematical ideas, students write down the data known from the questions so that students can determine the solution strategy. Furthermore, after the calculation is done and the correct results are obtained. You can see the communication that arises, they can pour ideas to answer questions. It is because researchers do not insist on using certain methods to solve problems. S1 and S2 are given the freedom to determine the method they use according to the concepts they already have.

Besides, high mathematics ability subjects have the ability to solve problems in more than one way. This is in line with the results of research by Nastahwid, Irawan, and Susanto (2016: 620) that from the students' answers, there are creative ideas that arise so that they can show mathematical communication and are challenged to answer questions without being fixated on just one way and not. stick to one formula only on the basic competencies that are being studied at that time. This is also reinforced by previous research conducted by Zuhrotunnisa (2015: 74) that the subject is able to interpret problems in a complex manner (the subject is able to compare one data with another).

\section{Medium Mathematics Ability Subject}

The following is an excerpt from an interview with SMMA on openended problems at WMCST 1.

Researchers: Are you ready to be interviewed?

SMMA : Ready

Researchers: After reading the questions, do you know the meaning of the questions?

SMMA : Yes, you know

Researchers: Furthermore, what is known from the question?

SMMA : The stage is upright with an upright size of $15 \times 5 \mathrm{~m}$ and $5 \times 5 \mathrm{~m}$, the cost of stage decoration per meter is $\operatorname{Rp} 5,000.00$ per meter, and the rental fee per meter

Researchers: Is anything else known?

SMMA : Nothing

Researchers: After you know what you mean and you know what the idea comes to your mind? 
SMMA : Draw a perpendicular stage

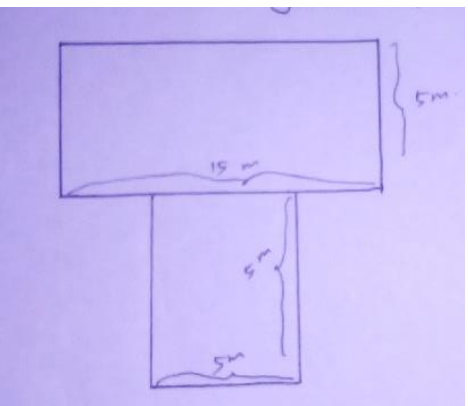

Researchers: In what ways did you come up with these ideas?

SMMA : by drawing a perpendicular stage

Researchers: Try to explain why you used this idea?

SMMA : To get results

Researchers: Next try expressing each step of the answer?

SMMA : The first one calculates the area of the stage, which is build 1 plus shape 2, namely $25 \mathrm{~m}+75 \mathrm{~m}=100 \mathrm{~m}$, the second is the circumference, namely $15+5+5+5+5+5+5+5=50$ so the cost of installing all decorations is $5000 \times 50=\operatorname{Rp} 250.000 .00$, the entire carpet is $8.000 \times$ the stage area $=8.000 \times 100=\operatorname{Rp} 800.000,00$

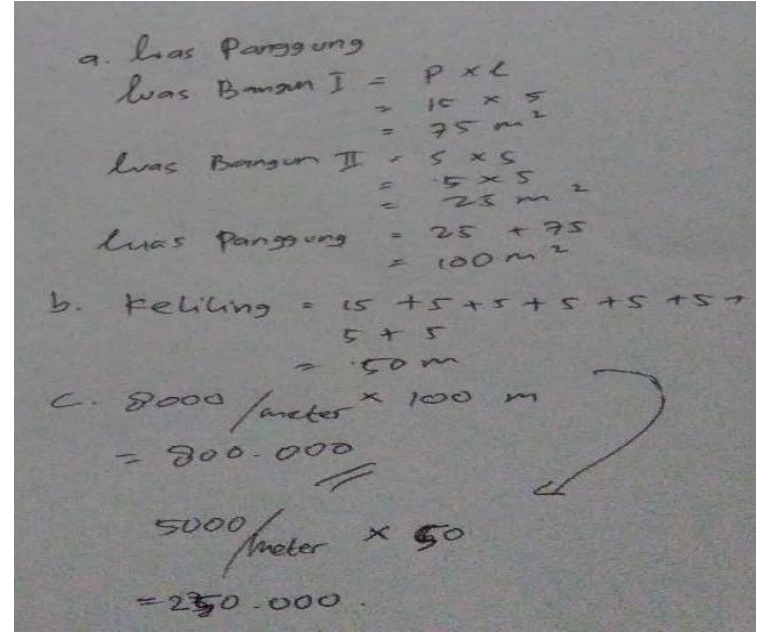

Researchers: How many buildings were there on that stage?

SMMA : There are two buildings. Build rectangles and squares

Researchers: Is there any other way to find the stage area?

SMMA : Nothing

Researchers: Is there any other way to find installation costs for the whole decoration?

SMMA : Nothing

Researchers: To find the entire carpet for rent, is there another way?

SMMA : No.

Researchers: After you have expressed all your answers, are you sure about your answer? 
SMMA : Yes, sure

Researchers: After solving the questions, are you used to proofread?

SMMA : sometimes

Researchers: What do you usually do to proofread again your answer?

SMMA : Recalculating from scratch.

Researchers: Please state what mathematical symbols or notations do you use in solving problems?

SMMA : Multiplication and addition.

Researchers: Why do you use symbols or mathematics notations?

SMMA : For easier finding the answer.

Researchers: What is the relationship between symbols or mathematics notations?

SMMA : To find out the results

The following is an excerpt from an interview with SMMA on Openended problems at WMCST 2.

Researchers: Are you ready to be interviewed?

SMMA : Yes

Researchers: After reading the questions, do you know the meaning of the questions?

SMMA : Yes, I know

Researchers: Furthermore, what is known from the question?

SMMA : L-shaped stage with an upright size of $6 \times 6 \mathrm{~m}$ while and $18 \times 6 \mathrm{~m}$ horizontally, around the stage, are decorated with decorations for Rp 15.000,00 per meter of decoration fee per meter and per meter rental fee

Researchers: Is anything else known?

SMMA : Nothing

Researchers: After you know what you mean and you know what the idea comes to your mind?

SMMA : Make two shapes

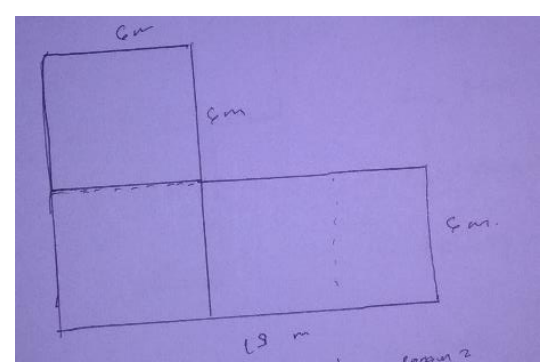

Researchers: In what ways did you come up with these ideas?

SMMA : By combining the two shapes to form an L-shaped stage

Researchers: Try to explain why you used this idea? 
SMMA : To answer questions

Researchers: Next try expressing each step of the answer you?

SMMA : The first one calculates the area of the stage, which is built one plus shape two, which results in $144 \mathrm{~m}^{2}$. And secondly, the cost of installing all the ornaments calculates the circumference first, namely $60 \mathrm{~m}^{2}$ and the installation cost of Rp 15.000,00 per meter, so $15.000 \times 60$ is $\operatorname{Rp} 900.000,00$. And thirdly, the rental fee for the entire stage area carpet plus the rental fee is $144 \times 18,000.00$ is Rp2.592.000,00

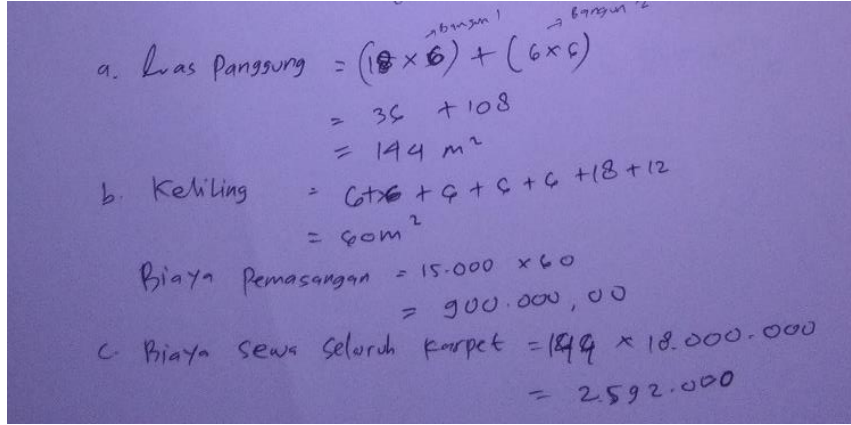

Researchers: How many buildings were there on that stage?

SMMA : There are two buildings. Square and rectangle

Researchers: Is there any other way to find the stage area?

SMMA : Nothing

Researchers: Is there any other way to find installation costs for the whole decoration?

SMMA : Nothing

Researchers: To find the entire carpet for rent is there any other way?

SMMA : Nothing

Researchers: After you have expressed all your answers, are you sure about your answer?

SMMA : God willing, sure

Researchers: After solving the questions, are you used to proofread?

SMMA : Sometimes

Researchers: What do you usually do in proofreading your answer?

SMMA : Recalculate from scratch.

Researchers: Please state what mathematical symbols or notations do you use in solving problems?

SMMA : Multiplication and addition.

Researchers: Why do you use symbols or notations in mathematics?

SMMA : To solve questions from questions

Researchers: What is the relationship between symbols or mathematical notation?

SMMA : That's how it is done 
Based on interview quotes and answers to subject with medium mathematics ability, it is revealed that subjects can meet all indicators of written mathematical communication skills, namely: Subject is able to express mathematical ideas through writing, demonstrate and convey visually; the subject is able to understand, interpret and evaluate mathematical ideas in writing, as well as in other visual forms; and the subject is able to use mathematical notations in their structure to write written ideas and relationships with situation models.

The subject is able to express mathematical ideas through writing by expressing the size of the stage as well as the cost of perimeter decoration and carpet rental costs and demonstrating and conveying visually by drawing a perpendicular stage. The subject is able to understand calculating the area of the stage, the cost of installing all the decorations, interpreting it by expressing the form of a stage consisting of 2 rectangular and square shapes, and evaluating mathematical ideas in writing, or other visual forms but unable to use different methods or able to finish in one way only. The subject is able to use mathematical notations of multiplication and addition to more easily find answers in their structure to write ideas and relationships with situation models in writing, namely to find out the results.

In general, it can be concluded that the subject with moderate mathematical ability can meet the three indicators of mathematical communication skills. This is in line with the results of research by Nastahwid, Irawan, and Susanto (2016: 620) that the students' answers show that students have met the communication standards of NCTM (2020). Like the answers shown by $S 1$ and S2, it can be seen in problem 1 that students have used mathematical language to express mathematical ideas correctly, namely making assumptions from each of the known data in the problem. Likewise, in problem 2, students have used mathematical language to express mathematical ideas correctly, namely making assumptions from each data that has been known in the problem. The first step that S1 and S2 take is to express their mathematical ideas, students write down the known data from the questions so that students can determine the solution strategy.

Furthermore, after the calculation is done and the correct results are obtained. It can be seen in the communication that arises. Students can express their opinions to answer questions. It is because researchers do not insist on using certain methods to solve problems. S1 and S2 are given the freedom to determine the method they use according to the concepts they already have. 
Besides, the moderate ability subject was only able to solve problems in one way. This is in line with the results of previous research conducted by Romadhon (2016: 169) that the subject is able to communicate the solution but not maximally. This is also reinforced by previous research conducted by Zuhrotunnisa (2015: 74) that the subject is still able to interpret problems simply.

\section{Low Mathematics Ability Subject}

The following is an excerpt from an interview with SLMA on open-ended problems at WMCST 1.

Researchers: Are you ready to be interviewed?

SLMA : Ready

Researchers: After reading the questions, do you know the meaning of the questions?

SLMA : I know

Researchers: Furthermore, what is known from the question?

SLMA : Pak Fikri plans to make the stage upright. With an upright size of $5 \mathrm{~m} \times 5 \mathrm{~m}$, while the horizontal size is $15 \mathrm{~m} \times 5 \mathrm{~m}$. Around the stage, decorations are installed for $\operatorname{Rp} 5.000,00$ per meter. The entire surface of the stage is covered with carpets with a rental fee of Rp. $8.000,00$ per $\mathrm{m}^{2}$.

Researchers: Is anything else known?

SLMA : Nothing.

Researchers: After you know what you mean and you know what the idea comes to your mind?

SLMA : Drawing a shape.

Researchers: In what ways did you come up with these ideas?

SLMA : by drawing two shapes that are put together.

Researchers: Try to explain why you used this idea?

SLMA : to answer questions on this issue.

Researchers: Next try expressing each step of the answer you?

SLMA : First determine the area of the stage, then after knowing the area of the stage determines the cost of installing all the decorations. The pair's cost of all the decorations is multiplied by the stage area you have been looking for. Finally, determine the rental fee for the entire carpet, also multiplied by the area you are looking for earlier. 

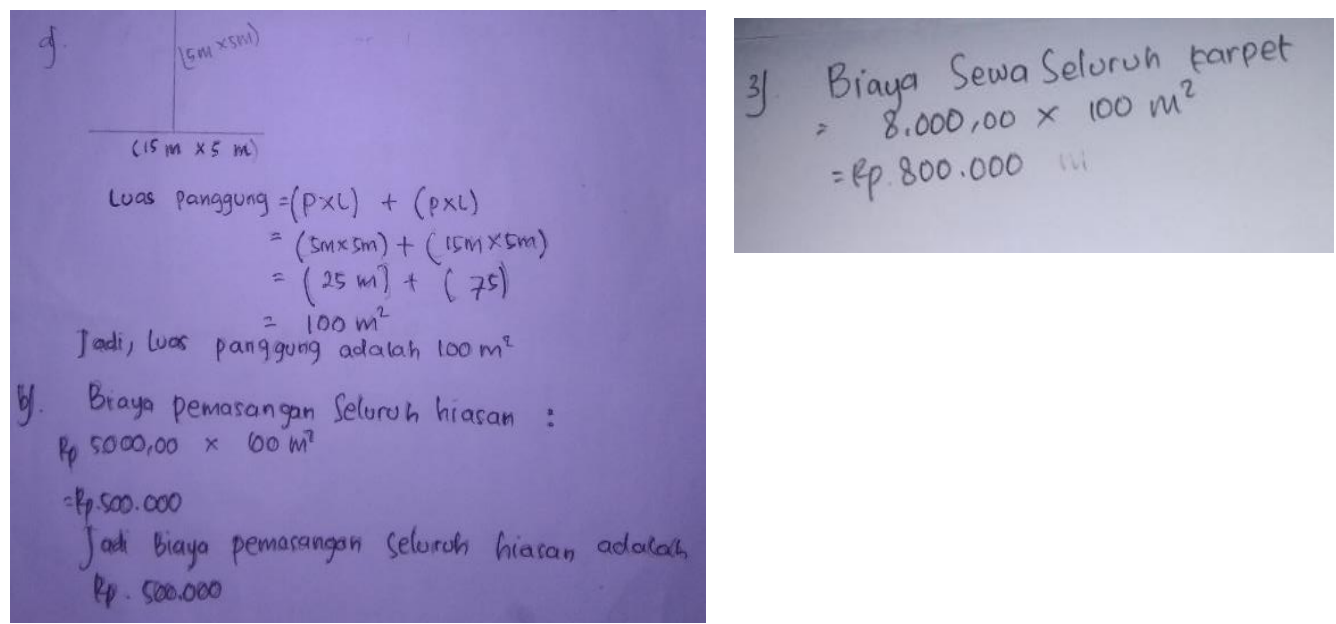

Researchers: How many buildings were there on that stage?

SLMA : There are two buildings. Build rectangles and squares

Researchers: How do you find the stage area?

SLMA $: p \times 1$ plus $p \times 1$ because it is perpendicular

Researchers: Is there any other way to find the stage area?

SLMA : I don't know

Researchers: Is there any other way to find installation fees for the whole decoration?

SLMA : Nothing

Researchers: To find the entire carpet for rent, is there another way?

SLMA : Nothing

Researchers: After you have expressed all your answers, are you sure about your answer?

SLMA : Yes, sure

Researchers: After solving the questions, are you used to proofread?

SLMA : Yes

Researchers: What do you usually do to proofread again your answer?

SLMA : By researching it again

Researchers: Please state what mathematical symbols or notations do you use in solving problems?

SLMA : Multiplication and addition.

Researchers: Why do you use symbols or notations in mathematics?

SLMA : To solve problems

Researchers: What is the relation between symbols or mathematical notation?

SLMA : Indeed a formula

The following is an excerpt from an interview with SLMA on open-ended problems at WMCST 2. 
Researchers: Are you ready to be interviewed?

SLMA : Yes

Researchers: After reading the questions, do you know the meaning of the questions?

SLMA : you know

Researchers: Furthermore, what is known from the question?

SLMA : L-shaped stage with an upright size of $6 \times 6 \mathrm{~m}$ and $18 \times 6 \mathrm{~m}$ horizontally, decoration fee of Rp 15.000,00 per meter, and rental fee of $\operatorname{Rp} 18.000,00$ per meter

Researchers: Is anything else known?

SLMA : Nothing

Researchers: After you know what you mean and you know what the idea comes to your mind?

SLMA : Draw an L-shaped stage

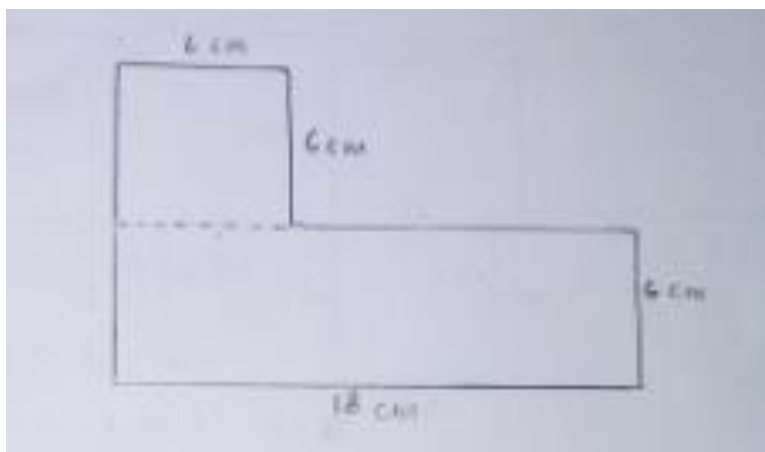

Researchers: In what ways did you come up with these ideas?

SLMA : By drawing two shapes that are put together

Researchers: Try to explain why you used this idea?

SLMA : To answer questions in this matter.

Researchers: Next try expressing each step of the answer you?

SLMA : Finding the area of the stage first, the cost of installing all the decorations by multiplying it by the area of the previous stage. Then determine the rental fee for the entire carpet multiplied by the stage area you were looking for. 


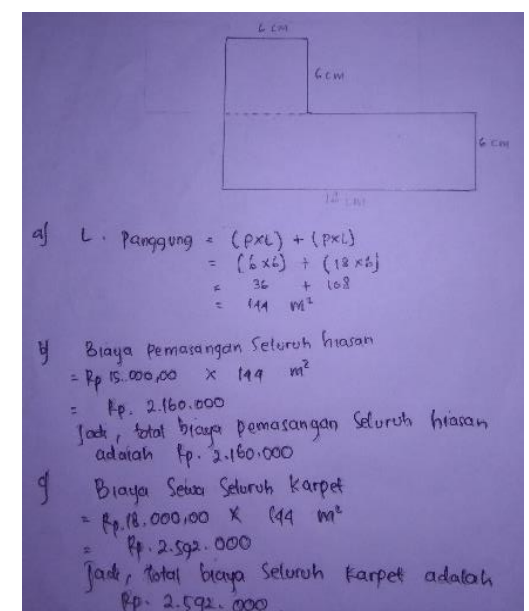

Researchers: How many buildings were there on that stage?

SLMA : There are 2 buildings. Build rectangles and squares

Researchers: How do you find the stage area?

SLMA : Find the area of a rectangle and find the area of a square. Then the result is $144 \mathrm{~m}^{2}$

Researchers: Is there any other way to find the stage area?

SLMA : Nothing

Researchers: Is there any other way to find installation costs for the whole decoration?

SLMA : No.

Researchers: To find the entire carpet for rent is there any other way?

SLMA : No.

Researchers: After you have expressed all your answers, are you sure about your answer?

SLMA : Yes, sure

Researchers: After solving the questions, are you used to proofread?

SLMA : Yes, I'm used to it

Researchers: What do you usually do in proofreading your answer?

SLMA : Count it back.

Researchers: Please state what mathematical symbols or notations do you use in solving problems?

SLMA : Multiplication and addition.

Researchers: Why do you use symbols or notations in mathematics?

SLMA : Because it is the formula for the area of the stage

Researchers: What is the relationship between symbols or mathematical notation?

SLMA : To find out the results.

Based on interview quotes and answers to subject with low mathematics ability, it is revealed that subjects can only fulfill two of the three indicators of 
written mathematical communication skills, namely: Subject is able to express mathematical ideas through writing, demonstrate and convey visually; the subject is not able to understand, interpret and evaluate mathematical ideas in writing or other visual forms; and the subject is able to use mathematical notation in its structure to write written ideas and relationships with situation models.

The student is able to express mathematical ideas through writing by drawing the stage and its size, the price of decoration per meter, and the price of renting a carpet per meter as well as demonstrating and conveying visually by drawing two shapes that are put together into a perpendicular stage, the subject is unable to understand, interpret and evaluate mathematical ideas in writing, as well as in other visual forms because the subject is unable to determine the cost of installing all the decorations and the cost of renting the entire carpet, and the subject is unable to use different methods, the subject is able to use mathematical notations of multiplication and addition to solve problems in its structure to write down ideas and relationships with the situation model in writing, namely to find answers or find out the results.

In general, it can be concluded that the subject with low mathematics ability can meet two of the three indicators of mathematical communication skills. Indicators that cannot be fulfilled are that the subject is unable to understand, interpret, and evaluate mathematical ideas in writing or other visual forms. This means that the subject with low mathematics ability cannot solve problems properly. This is in line with the results of previous research conducted by Romadhon (2016: 170) that the subject has not been able to answer calculation questions with a higher difficulty level, they have not been able to do the maximum and the right results. This is also reinforced by previous research conducted by Zuhrotunnisa (2015: 74) that the subject has not been able to express mathematical ideas in writing. Different subjects in open-ended problems judging from the achievement of indicators of written mathematical communication skills between high-ability, medium-skilled and low-skilled students, it can be seen that there are differences in students' mathematical communication skills. Based on the previous data analysis, the achievement of written mathematical communication skills indicators shows that high mathematics ability students can fulfill all indicators and it can be concluded that high-skilled subject can solve problems in more than one way. Moderate ability student can meet all indicators, and it can be concluded that moderate ability student is only able to solve problems in one way, and low ability student 
can fulfill two of the three indicators of mathematical communication skills in open-ended problems, namely: the first indicator and the third indicator and it can be concluded that low ability subject cannot solve problems properly. The indicator in question is that the subject is able to express mathematical ideas through writing, demonstrate and convey visually; and the subject is able to use mathematical notation in its structure to write written ideas and relationships with situation models.

\section{CONCLUSION}

Based on the results of the data analysis that has been described, it can be concluded that written mathematical communication skills in open-ended problems are as follows: (1) Subject with high mathematics ability can fulfill all three indicators of written mathematical communication skills, namely the subject is able to express mathematical ideas through writing, demonstrating and convey visually; the subject is able to express mathematical ideas through writing, demonstrate and convey visually; and subject is able to use mathematical notations in their structure to write ideas and relationships with situation models. (2) Subject with moderate mathematics ability can meet three indicators of written mathematical communication skills, namely subjects are able to express mathematical ideas through writing, demonstrate and convey visually; the subject is able to express mathematical ideas through writing, demonstrate and convey visually; and the subject is able to use mathematical notation in its structure to write ideas and relationships with situation models. (3) Subject with low mathematics ability can meet two of three indicators of written mathematical communication skills, namely subject is able to express mathematical ideas through writing, demonstrate and convey visually; the subject is unable to express mathematical ideas through writing, demonstrate and convey visually. (4) Subjects is able to use mathematical notations in their structure to write written ideas and relationships with situation models.

Some suggestions that the researcher can put forward are as follows: (a) Students' mathematics ability do vary so that teachers and prospective teachers pay more attention to the level of students' mathematics ability in learning, especially in training to solve problems and pay more attention to students with low and moderate ability so that their abilities could be better. (b) For mathematics teachers to be able to provide open-ended problem in learning so that students get used to working on open-ended problem and explain what 
open-ended questions are so that students do not doubt and worry about the answer.

\section{REFERENCES}

Agustyaningrum, N. (2011). Implementasi model pembelajaran learning cycle 5E untuk meningkatkan kemampuan komunikasi matematis siswa kelas IX B SMP Negeri 2 Sleman. Prosiding Pada Seminar Nasional Matematika dan Pendidikan Matematika dalam Pembelajaran dengan Tema Matematika dan Pendidikan Karakter dalam Pembelajaran. Yogyakarta: Pendidikan Matematika FMIPA UNY.

Ansari, B. (2003). Menumbuh kembangkan kemampuan pemahaman dan komunikasi matematika siswa melalui strategi Think-Talk-Write. Yogyakarta: Pustaka Pelajar.

Burghes, D., \& Robinson, D. (2009). Lesson study: enhancing mathematics teaching and learning. Plymouth UK: CfBT Education Trust, University of Plymouth.

Fraenkel, J., Wallen, N., \& H., H. (2008). How to design and evaluate research in education. New York: Mc Graw Hil I Companie.

Guerreiro, A., \& Serrazina, L. (2009). Communication as social interaction primary school teacher practices. Proceedings of the Sixth Congress of the European Society for Research in Mathematics Education. Lyon, France.

Hardjana, A. M. (2003). Komunikasi intrapersonal dan interpersonal. Yogyakarta: Kanisius (Anggota IKAPI).

Herdiana, H., Rohaeti, E. E., \& Sumarmo, U. (2017). Hard skills dan soft skills matematika siswa. Bandung: PT. Reflika Aditama.

Herdiana, H., Rohaeti, E. E., \& Sumarmo, U. (2018). Hard skills dan soft skills matematika siswa (Cetakan Kedua). Bandung: PT Rafika Aditama.

Inprasitha, M. (2006). Open-ended approach and teacher education. Tsukuba Journal of Educational Study in Mathematics, 27, 169-177. http://www. human.tsukuba.ac.jp/-mathedu/2514.pdf/.

Kaya, D., \& Aidin, H. (2014). Elementary mathematics teachers' perceptions and lived experiences on mathematical communication. Eurasia Journal of Mathematics, Science E Technology Education, 12(6), 1619-1629. https:// doi.org/10.12973/eurasia.2014.1203a.

Majid, A. (2016). Strategi pembelajaran (edisi VI). Bandung: PT Remaja Rosdakarya.

Nastahwid, M., Irawan, E. B., \& Susanto, H. (2016). Kemampuan komunikasi matematis siswa dalam pembelajaran sistem persamaan linear dua variabel menggunakan masalah open ended. Prosiding Pada Seminar Nasional Matematika Dan Pembelajarannya. Universitas Negeri Malang, Malang.

NCTM. (2020). Principles and standards for school mathematics. Reston VA: The 
National Council of Teachers of Mathematics, Inc.

Qohar, A. (2011). Pengembangan instrumen komunikasi matematis untuk siswa SMP. Prosiding Pada LSM XIX Lomba Dan Seminar Matematika. Pendidikan Matematika FMIPA Universitas Negeri Yogyakarta, Yogyakarta.

Romadhon, S. (2016). Analisis kemampuan komunikasi matematis siswa SMP pada materi kubus dan balok. Ekuivalen - Pendidikan Matematika, 20(3), 167-172. https:/ / doi.org/10.37729/ekuivalen.v20i3.2893.

Suherman, E., Turmudi, D. S., Herman, T., \& Suhendra, S. P. (2001). Strategi pembelajaran matematika kontemporer. Bandung: JICA-UPI.

Susanto, A. (2013). Teori belajar dan pembelajaran. Jakarta: Kencana Prenadamedia Group.

Syafitri, E., Saragih, E. M., \& Astuti, D. (2018). Mathematics learning by using learning model tapps to improve students' mathematical communication skill. The 11th International Workshop and Conference of Asean Studies in Linguistics, Islamic and Arabic Education, Social Sciences and Educational Technology 2018. https:/ / doi.org/10.31227/osf.io/3fcqm.

Wijaya, H. P. I., Sujadi, I., \& Riyadi. (2016). Kemampuan komunikasi matematis siswa sesuai dengan gender dalam pemecahan masalah pada materi balok dan kubus (studi kasus pada siswa SMP kelas VII SMP Islam AlAzhar 29 Semarang). Jurnal Elektronik Pembelajaran Matematika, 4(9), 778788. http://jurnal.fkip.uns.ac.id/index.php/s2math/article/view/9654 $/ 7105$.

Zuhrotunnisa. (2015). Deskripsi kemampuan komunikasi matematis siswa MTs. Negeri Bojong pada materi statistika. AlphaMath: Journal of Mathematics Education, 1(1), 1-12. https:/ / doi.org/10.30595/alphamath. v1i1.209. 